\title{
Innovation $\alpha$ : What Do IP-intensive Stock Price Indexes Tell Us About Innovation?
}

\author{
By CARol Corrado, DAVID MARTIN, AND QIANFAN WU*
}

\section{Online Appendix}

Contents:
A. Additional background
B. Introduction to Morphogenetics
C. Innovation Cohorts: Examples
D. Index Performance: Charts
E. Patent Counts and Commercial Scores
a. Method
b. Results
c. The FactSet Company Classification System

\section{A. Additional Background}

As one of the most significant forms of intellectual property (IP), patents may not only be valuable to the individuals and organizations that possess them but may also be used to infer the dynamics and context of the innovations they disclose (Kline et al., 2019). Analyzing patents devoid of their contexts, including the prevailing legal and patent office approval practices, does not yield a complete picture of the value of innovation (Martin, 2001). Consequently, some studies (Yoon et al., 2004; Erdi et al., 2013; Mariani et al, 2017) have adopted network citation analysis to discover the complex hidden values within patent citation networks. These studies, as well as the traditional approach in the economics literature, generally take a simple quantitative approach, assuming that the value of an organization's patent portfolio increases if they have greater patent numbers and patent citation counts. Here, we take the position that patent and citation counts are

\footnotetext{
* We thank Christos Makridis and Nicholas Wales for helpful comments on an earlier draft.
} 
generally poor measures of innovation activity due to the limited scope and potential information they can convey. As indicated in the main text, unlike academic or artistic works, patent citations can delimit the options of prior innovation, often defining a narrowing of market options construed from the referenced patent.

Additionally, patents vary in purpose (e.g., defensive vs offensive, Pavitt 1988) and quality (e.g., Griliches, 1990). From a commercial standpoint, a higher citation count may indicate reduced patent novelty due to the existence of competitors in the marketplace, as well as a narrowing of the inferred scope of the invention claimed, factors not generally acknowledged in the economics literature (e.g., for a review of commonly used metrics, see Squicciarini et al., 2013). Previous citation network research seeks to interleave citations and keywords to define quality or importance (Yoon et al., 2004; Tseing et al., 2007). Unfortunately, as patent applicants can be their own 'lexicographer' under the statute and under judicial review, keywords fail to acknowledge the use of metaphor (both overt and covert) that masks the ordinary meaning of words or concepts. All these challenges present the need for developing a methodology that effectively analyses patent novelty and related commercial value to fully understand the environment in which innovation drives market value.

\section{B. Introduction to Morphogenetics}

Our work introduces a patent innovation inference network analysis tool ("morphogenetics") that has been developed to determine the likely uniqueness and novelty of a subject patent. An explanation of the morphogenetic tool is shown in Figure 1. The figure illustrates a patent citation network between a patent, call it " $X$ ", and a subject patent (Label: 110). The arrows in the figure indicate the direction of a citation, with the triangle icons represent first order relationship between " $\mathrm{X}$ " and the subject patent, and the circle icons represent second order relationship between " $\mathrm{X}$ " and the subject patent. Icons labelled 120 - 170 demonstrate the statuses patent " $X$ " can have with respect to the subject 110. Patent " $X$ " can be in one or multiple statuses

with respect to 110 . We call Patent " $X$ " the prior art of subject 110 if " $X$ " is in status 120 , meaning " $X$ " is cited by 110 . We call " $X$ " the subsequent art of 110 if " $X$ " is in status 150 , in which case " $\mathrm{X}$ " cites 110. If " $\mathrm{X}$ " is in status 160 , it means " $\mathrm{X}$ " is the prior art of patents citing 110 . If " $\mathrm{X}$ " is in status 140 , it means " $X$ " is the subsequent art of the patents cited by 110 . In addition, if " $X$ " is both in status 140 and 160 , it means " $\mathrm{X}$ " is the both the subsequent art of the patents cited by 110 , 
as well as the prior art of patents citing 110. Patent " $\mathrm{X}$ " doesn't cite or is cited by the subject 110 directly except in the status 120 or 150 .

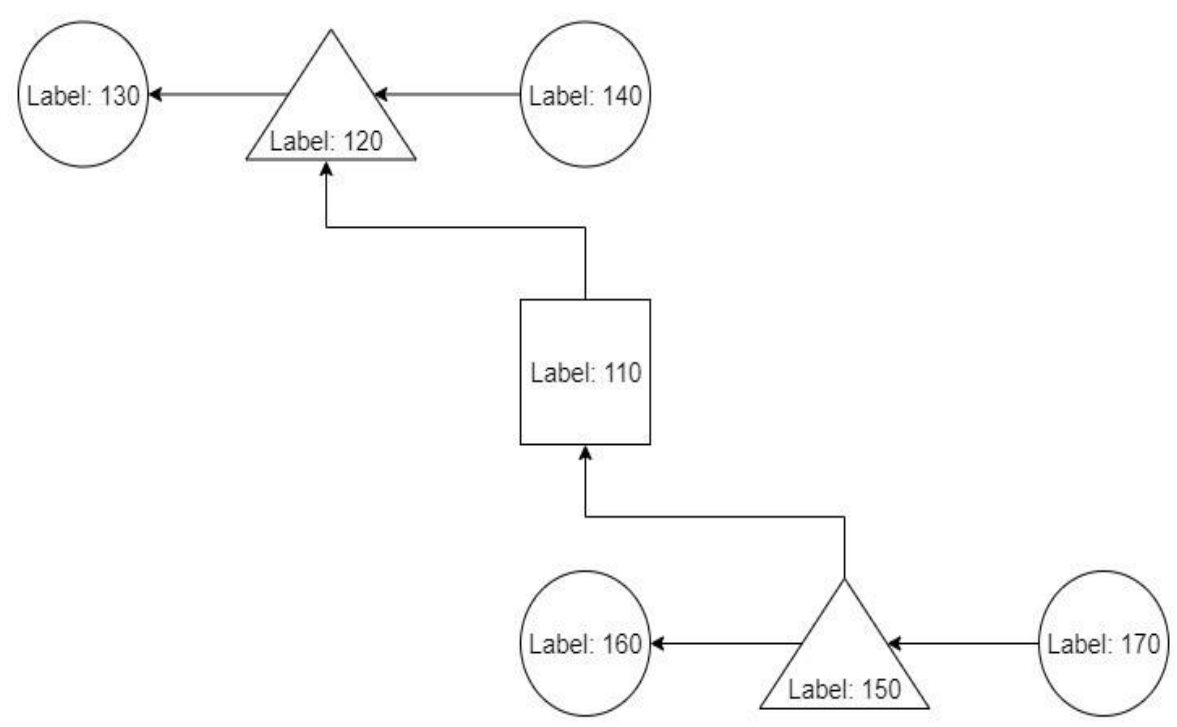

\section{FIGURE A.1: AN ILLUSTRATION OF THE RELATIONSHIP BETWEEN PATENT " $X$ " AND THE SUBJECT PATENT LABELLED 110}

The morphogenetic tool seeks to uncover "thesaurus" patents by detecting work that other related patents and patent examiners have identified as conforming to the legal standard of relevance, but which were not cited by the subject patent. The more there are relevant works identified in the network analysis that were not cited, the higher the likelihood that the target patent is a functional redundancy. From this we can conclude that a patent is moderately to severely impaired and of limited commercial value.

For any given subject patent, by using the morphogenetic analysis, we can further identify 2 categories based on the attributes of patent " $\mathrm{X}$ " and its implied impact on the subject patent. These two categories are illustrated in Table A.1. A patent tends to have limited novelty and uniqueness if there are several other patents which are categorized as "Likely Threat" with respect to the subject patent. In contrast, originality and commercial value of the subject patent are likely to be higher with the existence of other patents categorized as "Likely Opportunity". For example, a patent "X" will be categorized as "Likely Threat" to the subject patent if it has statuses 140, 160, and 170. We expect the novelty of commercial value of the subject patent to decrease due to the existence of several patents similar to "X". On the other hand, patent "Y" will be categorized as "Likely Opportunity" to the subject patent if it has statuses 160 and 170, indicating the subject 
patent may increase its commercial value by utilizing and enforcing potential licensing opportunity.

Table A.1-Morphogenetic Categories

\begin{tabular}{|c|l|}
\hline CATEGORY & \multicolumn{1}{|c|}{ PATENT ATTRIBUTES AND EXPLANATION } \\
\hline Threat & $\begin{array}{l}\text { Patents in this group: } \\
\text {--Have a priority date preceding the subject patent, identified by the system as having } \\
\text { claims language sufficiently consistent with that of the subject patent to be included in the } \\
\text { innovation space of the subject patent yet were not cited by subject patent. } \\
\text {--Or, were undergoing office action at the same time as the subject patent during some } \\
\text { period of the subject patent's prosecution history, but neither cite nor are cited by the } \\
\text { subject patent. }\end{array}$ \\
\hline $\begin{array}{l}\text { Likely } \\
\text { This group contains patents with highest potential prior or concurrent innovation relevance } \\
\text { to the subject patent. It also singles out cases of probable "reverse engineering," the } \\
\text { practice of creating a patent based largely on the innovative steps of an ancestral patent, } \\
\text { while taking steps during the prosecution of a patent to obscure a citation connection. }\end{array}$ \\
\hline $\begin{array}{l}\text { Patents in this group: } \\
\text { Opportunity }\end{array}$ \\
$\begin{array}{l}\text { sufficiently consistent with that of the subject patent to be included in the innovation space } \\
\text { of the subject patent yet did not cite the subject patent. } \\
\text { In this group one may identify potential licensing opportunities as the enforceability or } \\
\text { commercial validity of patents in this group could be limited by the claims of the subject } \\
\text { patent. }\end{array}$ \\
\hline
\end{tabular}

\section{Innovation Cohorts: Examples}

An innovation cohort consists of companies against which the sentinel company competes most closely with regard to innovation, i.e., companies whose morphogenetic threat scores vis a vis the sentinel company are the highest. Tables A.2 and A.3 show the cohort members of two sentinel companies, Apple, Inc. and Proctor \& Gamble Company, as of September 1, 2019.

Table A.2: Innovation Cohort Members for Apple Inc. on 9/1/2019

\begin{tabular}{lll}
\hline & Company Name & Sector \\
\hline Sentinel Company: & Apple Inc. & Electronic Technology \\
\hline \hline Cohort Members: & Microsoft Corporation & Technology Services
\end{tabular}


International Business Machines

Corporation

Sony Corporation Sponsored ADR

Nokia Oyj Sponsored ADR

HP Inc.
Technology Services

Consumer Durables

Electronic Technology

Electronic Technology

Note: FactSet Industries and Economic Sectors Classification System is used to determine the company sectors. FactSet Online Assistant ${ }$, Page ID 6739.25293. See Appendix E for more details.

Table A.3: Innovation Cohort Members for Procter \& Gamble Company on 9/1/2019

\begin{tabular}{lll}
\hline & Company Name & Sector \\
\hline Sentinel Company: & Proctor \& Gamble Company & Consumer Non-Durables \\
\hline Cohort Members: & Kimberly Clark Corporation & Consumer Non-Durables \\
& 3M Company & Producer Manufacturing \\
& Johnson \& Johnson & Health Technology \\
& Colgate-Palmolive Company & Consumer Non-Durables \\
& Pfizer Inc. & Health Technology \\
\hline
\end{tabular}

Note: FactSet Industries and Economic Sectors Classification System is used to determine the company sectors. FactSet Online Assistant ${ }^{\circledR}$, Page ID 6739.25293. See Appendix E for more details. 


\section{Index Performance: Charts}

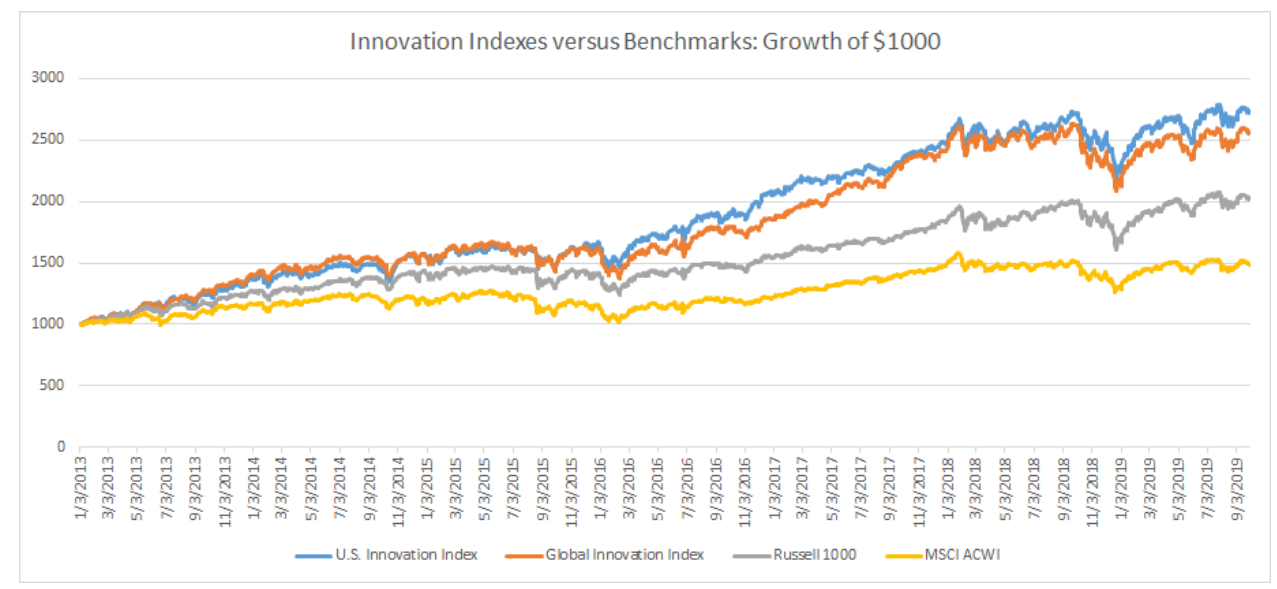

FIGURE A.2: INNOVATION $\alpha$ INDEXES PERFORMANCE VERSUS THEIR BENCHMARKS.

Note: The Morgan Stanley Capital International (MSCI) all country world index (ACWI) is a market capitalization weighted index designed to provide a broad measure of world equity-market performance.

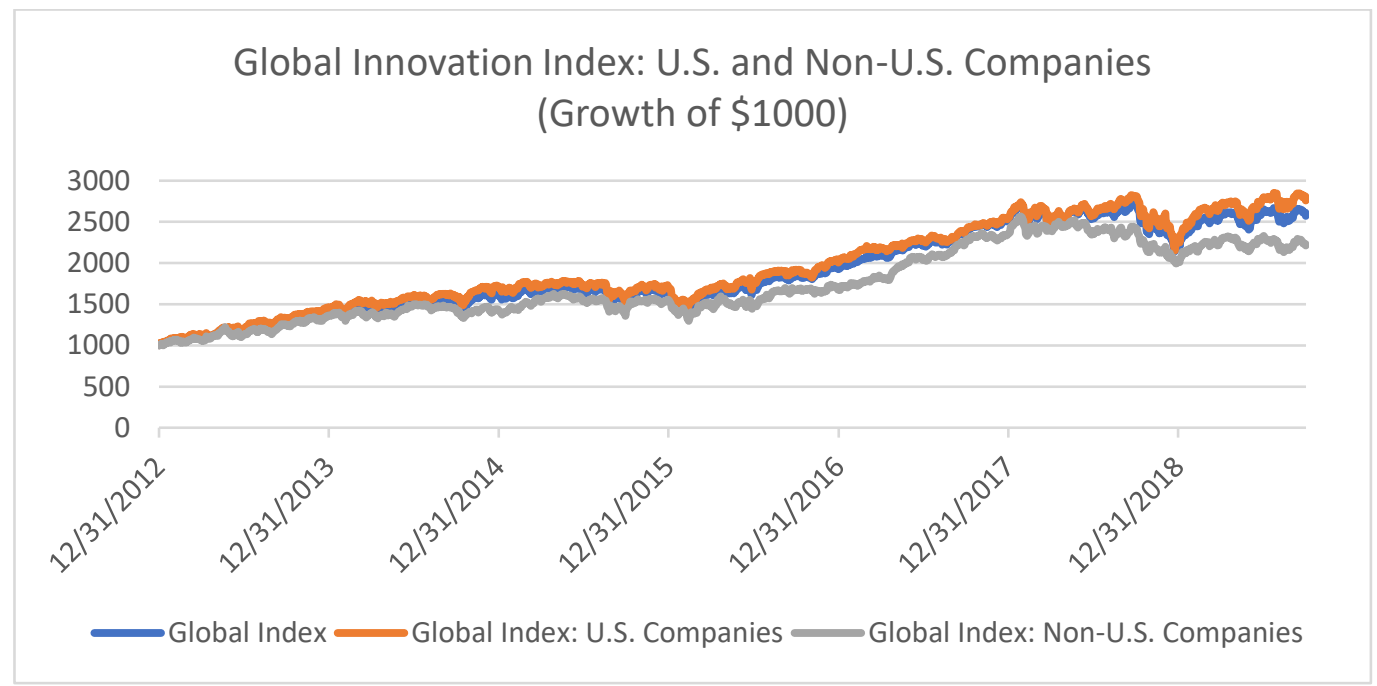

FIGURE A.3: U.S. AND NON-U.S. COMPANIES: COMPONENTS OF THE INNOVATION $\alpha$ GLOBAL INDEX. Note: Based on the selection algorithm, the Global Index consists of 74 U.S. companies and 46 non-U.S. companies as of September 2019.

\section{E. Patent Counts and Commercial Scores}

In addition to the index methodology introduced in the main text, we propose a commercial score measure to evaluate the commercial value of a company's patent portfolio. 


\section{(a) Method}

If a patent is categorized as "Likely Opportunity" through the morphogenetics, one may identify commercialization opportunities against the patent due to the limited innovation scope defined by the subject patent. We define a subject patent as a "commercializable patent" if another patent owned by a different organization exists in the "Likely Opportunity" category subject to the patent under review. Note also that a patent is categorized as "Likely Opportunity" only if it was filed after the subject patent. Data for some patents, especially the international equivalents for the primary patent, may be incomplete due to the variation in filing standards between different patent offices. Consequently, we only consider the patents with complete data in our commercial score calculation and define them as "scorable patents".

We define the commercial score $C S_{i}$ as the percentage of commercializable patents among the patent portfolio:

$$
C S_{i}=C_{i} /_{N_{i}} * 100 \%
$$

where $C_{i}$ is the number of commercializable patents and $N_{i}$ is the total number of scorable patents. The commercial score evaluates the overall potential quality of a patent in the marketplace. It is also an indicator of the commercial quality of a company's patent portfolio when aggregated.

Commercial scores for two economic sectors: healthcare technology (pharma, biotech, medical devices, etc.) and telecommunications (equipment and services). The FactSet Industries and Economic Sectors Classification System was used to determine the sectors and industries for companies; details on this classification system are provided below. We selected 355 companies for the health technology sector and 43 for the telecommunications sector. The healthcare companies were selected by reviewing and combining the holdings of several well-recognized healthcare indexes and Exchange Traded Funds (ETFs), such as the Health Care Select Sector SPDR ${ }^{\circledR}$ and the MSCI World Healthcare Index. For telecommunications, we selected companies falling into these sectors from a universe consisting of all sentinel companies and cohort members in our U.S. and Global indexes as of July 1, 2019. Descriptive data for the companies are shown in Table A.4. 


\section{Table A.4: Descriptive data of companies selected for commercial score calculation}

\begin{tabular}{ccccc}
\hline & $\begin{array}{c}\text { No. of } \\
\text { companies }\end{array}$ & $\begin{array}{c}\text { Average } \\
\text { market cap } \\
\text { (billion \$) }\end{array}$ & $\begin{array}{c}\text { Average No. } \\
\text { of scorable } \\
\text { patents }\end{array}$ & $\begin{array}{c}\text { Std. Dev. } \\
\text { of scorable } \\
\text { patents }\end{array}$ \\
\hline $\begin{array}{c}\text { Healthcare technology } \\
\text { U.S. Companies }\end{array}$ & 199 & 19.26 & 915.39 & 2704.70 \\
$\begin{array}{c}\text { Non-U.S. Companies } \\
\text { Telecommunications }\end{array}$ & 156 & 13.14 & 823.32 & 2356.07 \\
U.S. Companies & 22 & 24.12 & 6709.14 & 13939.50 \\
Non-U.S. Companies & 21 & 111.61 & 2535.38 & 5358.29 \\
\hline
\end{tabular}

Note: For the healthcare technology sector, the number of scorable patents account for $44.37 \%$ of the total granted patents for U.S. companies, $63.54 \%$ for Non-U.S. companies; For the telecommunications sector, the number of scorable patents account for $49.18 \%$ for U.S. companies, $68.97 \%$ for Non-U.S. companies.

(b) Results

We calculated the commercial scores for companies in the two sectors and then grouped them by U.S. companies and non-U.S. companies. The results are presented in Figure A.4. In general, the percentage of commercializable patents held in the telecommunications sector is higher than the percentage of those held in the healthcare technology sector, by approximately 20 percent. Figure A.3 further shows that non-U.S. companies in both sectors have a higher percentage of commercializable patents. The differences in commercial scores between U.S. and Non-U.S. companies are possibly the consequences of the differences in patent law, competition intensity, and emphasis on R\&D investments. Additionally, it is potentially the case that international companies have lower dependency on patent thickets for litigation risk management when compared to their U.S. counterparts. The data we calculate also indicates that U.S. companies are more likely to file "defensive" patents. On the other hand, non-U.S. companies are more inclined to file forward-looking patents purely for innovation purposes. 


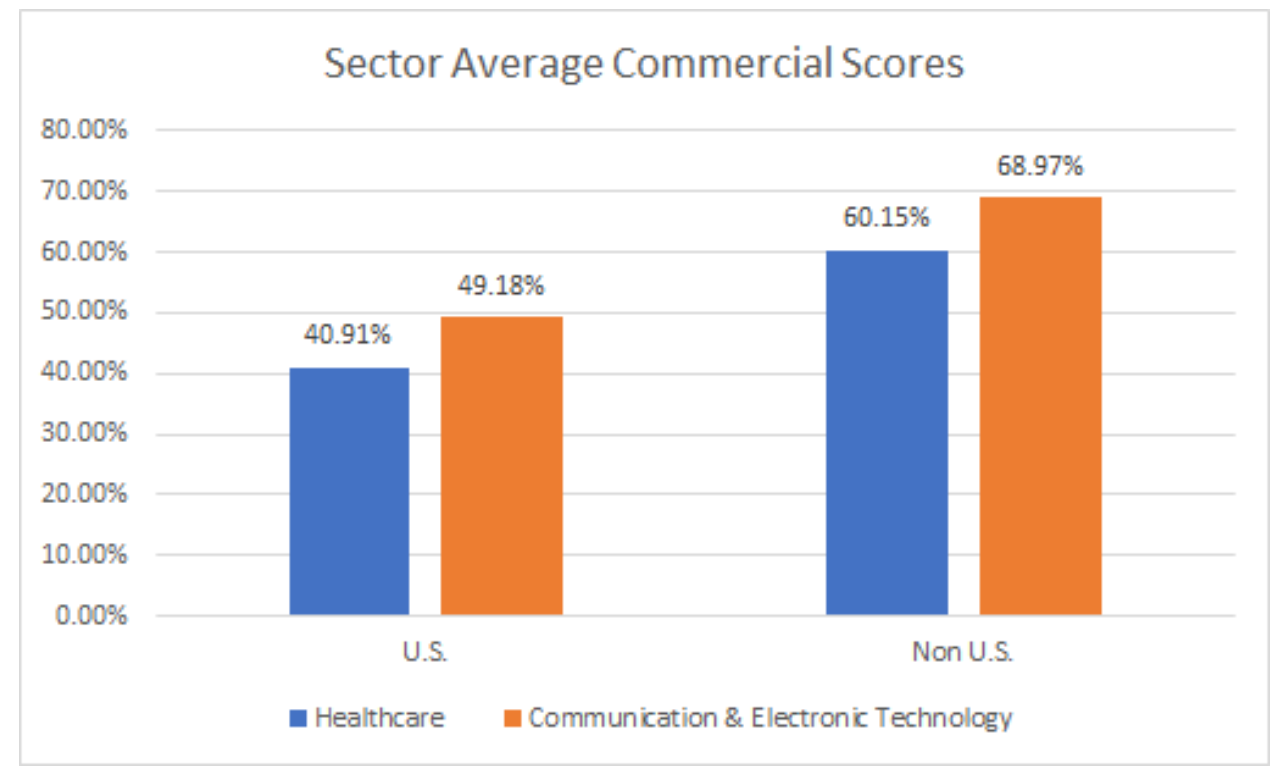

FIGURE A.4: COMMERCIAL SCORES FOR U.S AND NON-U.S. COMPANIES FOR THE HEALTH TECHNOLOGY AND TELECOMMUNICATIONS SECTORS

A further examination of the commercial scores involves breaking down the two sectors into several sub-industries. Because the industry distribution is highly skewed, we grouped only the top 5 sub-industries by company counts for the health tech sector and the telecommunication sector to avoid sub-population bias. The result for the two sectors is shown in Figures A.5 and A.6. Within the health technology sector, companies in the pharmaceutical industry tend to have higher commercial scores whereas scores for companies in medical specialties are slightly lower. This result is not surprising given that the pharmaceutical industry is known to rely heavily on innovation activities, with R\&D expenditures higher than most of other industries (OECD 2017). Our data reinforce this result by demonstrating that the patent portfolios of pharmaceutical companies tend to have higher market values.

Within telecommunications, the wireless telecommunications industry achieved the highest level of commercial scores. Several companies in this industry have large patent portfolios and leading individual commercial scores as well. For example, Japanese company NTT DOCOMO INC has 6952 scorable granted patents and $79.47 \%$ of them are considered commercializable. On the other hand, the Computer Communications industry possessed the least commercial percentage among the top 5. However, since the population size within this industry is limited, further examination across a larger population size over this sector is expected in the future. 


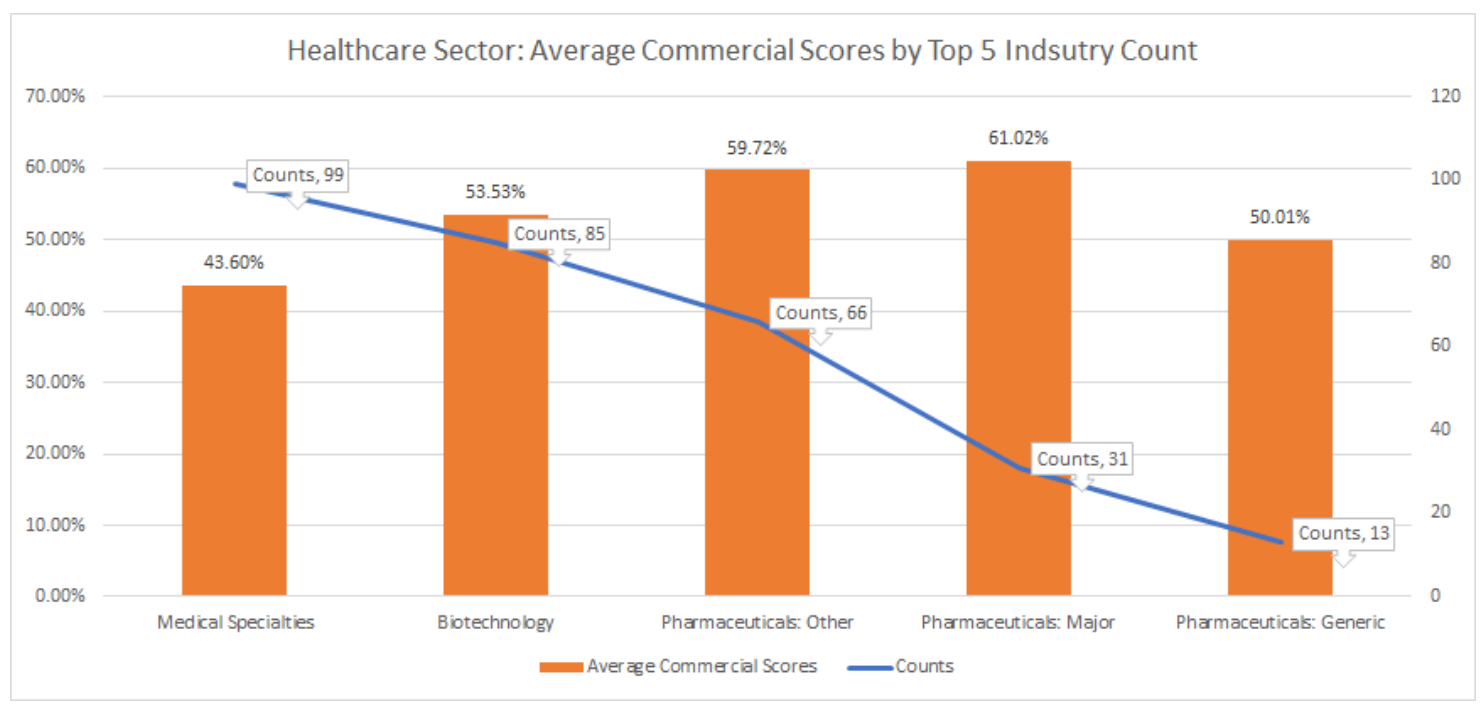

FIGURE A.5: AVERAGE COMMERCIAL SCORES BY TOP 5 INDUSTRY COUNT WITHIN THE HEALTH TECHNOLOGY SECTOR

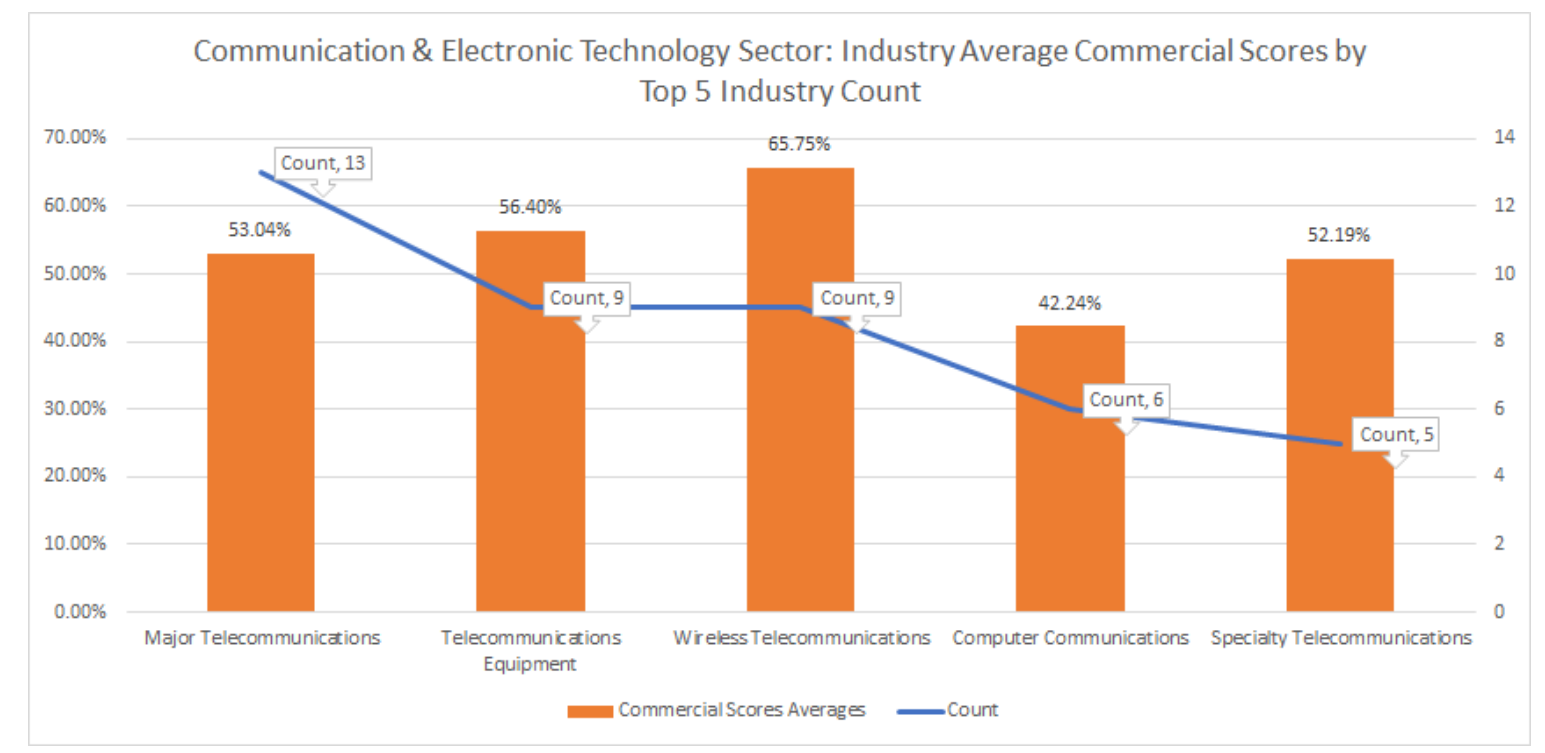

FIGURE A.6: THE AVERAGE COMMERCIAL SCORES FOR THE 5 INDUSTRIES WITHIN THE TELECOMMUNICATIONS SECTOR

The commercial score calculation for the two sectors under review suggests that non-U.S. companies generally have a higher percentage of commercializable patents than their U.S. counterparts. Yet, as also shown in figure A.4, the US companies sub-index of the Global index outperform non-U.S. companies, suggesting that U.S. firms exploit synergies with other intangible assets, e.g., organizational capital and/or the deployment of IT (e.g., Bloom et al., 2012). In the future, more research is expected on developing more efficient and effective analytical methods to explain the market value variance of companies by using patent and other intangible capital 
statistics and conducting deeper examinations on the patent portfolio quality across sectors, industries, and geographical areas.

\section{(c) The FactSet Company Classification System}

FactSet maintains a proprietary industry classification system in which every company carried in any of the fundamental databases on FactSet is assigned to a FactSet industry. The industries are organized into four general economic categories:

- Durables

- Non-durables

- $\quad$ Services

- Infrastructure

The first three of these (Durables, Non-durables, and Services) are cross-referenced into four economic sectors:

- Materials

- Producer

- Technology

- Consumer

The fourth general category, Infrastructure, incorporates services that are pervasive throughout the economy: transportation, utilities, finance, and communication services.

The resulting matrix generates a coherent and relevant organization of potentially investable corporations. One of the primary goals in this enterprise is to try to identify patterns of economic and industrial change that may not be as readily discernible elsewhere. The contact information for more details on the system is provided on the following website. https://www.factset.com/contact-us.

In our analysis, the healthcare sector includes two healthcare related FactSet economic sectors drawn from the classification system: Health Technology and Health Service. The communication \& electronic technology sectors include two related FactSet economic sectors: communication and electronic technology. These FactSet sectors were combined to form the two "broader" sectors in our analysis. Their descriptions of the sub-industries shown in figures A.4 
and A.5 are described below, and a table showing examples of companies included in groups follows.

Healthcare sector:

- Medical Specialties: This industry group consists of companies that develop and manufacture equipment and technologies designed specifically for the healthcare industry. Examples: Dialysis equipment, bacterial and viral identification kits, hygiene control equipment, blood analysis equipment, precision equipment, laboratory automation equipment, and patient monitoring systems, disposable bed pads, catheters, surgical equipment, and other medical diagnostic equipment.

- Biotechnology: This industry group consists of companies involved in the application of genetic engineering (genomics) and/or protein engineering (proteomics) to produce therapeutic and preventive medicine. and medical diagnostic products. Companies that manufacture biotechnology equipment and provide services to the biotech industry are also included in this industry.

- Pharmaceuticals: Major: This industry group consists of companies that discover, develop, and manufacture chemically based therapeutic and preventive medicine, and other medicinal products. Companies included in this industry generally oversee the entire drug development process (research, testing, production, distribution, etc.). Examples: Cardiovascular and anti-cancer drugs, antibiotics, vaccines, contraceptives, mental health products, and cough and cold medicine.

- Pharmaceuticals: Other: This industry group consists of companies that either discovers, develop, or manufacture chemically based therapeutic and preventive medicine, and medicinal products. Companies included in this industry tend to collaborate with other pharmaceutical companies.

- Pharmaceuticals: Generic: This industry group consists of companies engaged in the manufacture of generic therapeutic and preventive medicine, and other medicinal products.

\section{Communication \& electronic technology sector:}

- Computer Communications: This industry consists of companies engaged in the manufacturing of computer connectivity and network products. Example: Routers, remote access servers, applications for Token Ring, Ethernet, and other high-speed networks, shared media hubs, local area networks (LAN) and wide-area networks (WAN), and Internet protocol (IP) products.

- Major Telecommunications: This industry group consists of companies that operate, maintain, and/or provide voice and data transport services based on multiple transmission (fixed line, digital subscriber line (DSL) technology, competitive local exchange carriers (CLEC), Internet-based communication services, wireless, etc.) technologies. Example: Local and long distance telephone services, message telecommunication services, 
wireless services, Internet access (both cable and integrated services digital network (ISDN)), and directory and calling card services.

- Wireless Telecommunications: This industry group consists of companies that provide wireless antenna- or satellite-based telecommunication services. Example, Beeper and paging services, specialized mobile radio (SMR) services, and other wireless communication services.

- Telecommunications Equipment: This industry group consists of companies engaged in the manufacturing of voice and data communications equipment. Example: Fiber optic delivery products, digital signal processing (DSP), high speed voice, data, and video delivery and access platforms, global positioning systems (GPS), satellite systems, paging and wireless data systems, personal communication equipment and systems, twoway land mobile systems, wireless microcell systems, private branch exchange switches (PBX), telephone handsets, residential systems, and payload equipment for satellites.

- Specialty Telecommunications: This industry group consists of companies that operate, maintain, and/or provide voice and data transport services based on a single transmission (fixed-line, digital subscriber line (DSL) technology, Internet-based communication services, etc.) technology, and/or cover a specific market (facilities-based, competitive local exchange carriers (CLEC), etc.). Companies that provide services to the telecommunication industry are also included in this industry.

Table A.5: Examples of companies included in the commercial score calculation

\begin{tabular}{|l|l|l|}
\hline Sub-Industry & Sector & $\begin{array}{l}\text { Examples of Companies included in } \\
\text { Commercial Score Computation }\end{array}$ \\
\hline Medical Specialties & Health Technology & $\begin{array}{l}\text { Abbott Laboratories; Medtronic, Inc; } \\
\text { Thermo Fisher Scientific, Inc. }\end{array}$ \\
\hline Biotechnology & Health Technology & $\begin{array}{l}\text { Amgen, Inc; Gilead Sciences, Inc; CSL } \\
\text { Limited }\end{array}$ \\
\hline Pharmaceuticals: Major & Health Technology & $\begin{array}{l}\text { Johnson \& Johnson; Pfizer, Inc; Novartis } \\
\text { AG }\end{array}$ \\
\hline Pharmaceuticals: Other & Health Technology & $\begin{array}{l}\text { Bayer AG; Daiichi Sankyo Co., Ltd.; } \\
\text { Chugai Pharmaceutical Co., Ltd. }\end{array}$ \\
\hline Pharmaceuticals: Generic & Health Technology & Zoetis, Inc; Allergan, Inc.; Mylan, Inc. \\
\hline Computer Communications & Electronic Technology & $\begin{array}{l}\text { Fortinet, Inc.; Arista Networks, Inc.; Cisco } \\
\text { Systems, Inc. }\end{array}$ \\
\hline Major Telecommunications & Communications & $\begin{array}{l}\text { BCE Inc; Deutsche Telekom AG; Royal } \\
\text { KPN NV }\end{array}$ \\
\hline Wireless Telecommunications & Communications & $\begin{array}{l}\text { Rogers Communications Inc; Sprint } \\
\text { Corp.; T-Mobile US, Inc. }\end{array}$ \\
\hline $\begin{array}{l}\text { Telecommunications } \\
\text { Equipment }\end{array}$ & Electronic Technology & $\begin{array}{l}\text { Nokia Oyj; Garmin Ltd.; QUALCOMM } \\
\text { Incorporated }\end{array}$ \\
\hline Specialty Telecommunications & Communications & $\begin{array}{l}\text { SoftBank Group Corp.; SES SA; } \\
\text { CenturyLink, Inc. }\end{array}$ \\
\hline
\end{tabular}




\section{ADDITIONAL REFERENCES}

Balsmeier, B., Assaf, M., Chesebro, T., Fierro, G., Johnson, K., Johnson, S., Li, G.C., Lück, S., O'Reagan, D., Yeh, B. and Zang, G., 2018. Machine learning and natural language processing on the patent corpus: Data, tools, and new measures. Journal of Economics \& Management Strategy, 27(3), pp.535-553.

Cockburn, I.M. and Griliches, Z., 1987. Industry effects and appropriability measures in the stock markets valuation of $R \& D$ and patents.

De Rassenfosse, G. and de la Potterie, B.V.P., 2009. A policy insight into the R\&D-patent relationship. Research Policy, 38(5), pp.779-792.

Érdi, P., Makovi, K., Somogyvári, Z., Strandburg, K., Tobochnik, J., Volf, P. and Zalányi, L., 2013. Prediction of emerging technologies based on analysis of the US patent citation network. Scientometrics, 95(1), pp.225-242.

Griliches, Z., 1990. Patent statistics as economic indicators: A survey. Journal of Economic Literature 28:4 (December), pp 1661-1707.

Hall, B.H., Jaffe, A. and Trajtenberg, M., 2005. Market value and patent citations. RAND Journal of Economics, pp.16-38.

Hu, J., Li, S., Yao, Y., Yu, L., Yang, G. and Hu, J., 2018. Patent keyword extraction algorithm based on distributed representation for patent classification. Entropy, 20(2), p.104.

Jaffe, A.B. and Trajtenberg, M., 2002. Patents, citations, and innovations: A window on the knowledge economy. MIT press.

Jaffe, A.B. and Lerner, J., 2004b. Patent Prescription: A radical cure for the ailing [US patent policy]. IEEE Spectrum, 41(12), pp.38-43.

Kline, P., Petkova, N., Williams, H. and Zidar, O., 2019. Who profits from patents? Rent-sharing at innovative firms. The Quarterly Journal of Economics, 134(3), pp.1343-1404.

Lanjouw, J.O., Pakes, A. and Putnam, J., 1998. How to count patents and value intellectual property: The uses of patent renewal and application data. The Journal of Industrial Economics, 46(4), pp.405-432.

Mariani, M.S., Medo, M. and Lafond, F., 2017. Early identification of important patents through network centrality. arXiv preprint arXiv:1710.09182.

Martin, David E. 2001. Patents: Improving Quality and Curing Defects: Hearing Before the Subcommittee on Courts, the Internet, and Intellectual Property of the Committee on the 
Judiciary House of Representatives, 107th Congress, First Session (May 10).

http://commdocs.house.gov/committees/judiciary/hju72305.000/hju72305_0f.htm

OECD (2017), "Research and development in the pharmaceutical sector", in Health at a Glance 2017: OECD Indicators, OECD Publishing, Paris, https://doi.org/10.1787/health_glance-201772-en.

Pavitt, K., 1988. Uses and abuses of patent statistics. In Handbook of quantitative studies of science and technology (pp. 509-536). Elsevier.

Squicciarini, Mariagrazia, Hélène Dernis, and Chiara Criscuolo. 2013. "Measuring Patent Quality: Indicators of Technological and Economic Value.” OECD DSTI Working Papers, 2013/03, OECD Publishing.

Trappey, A.J., Trappey, C.V., Wu, C.Y. and Lin, C.W., 2012. A patent quality analysis for innovative technology and product development. Advanced Engineering Informatics, 26(1), pp. 26-34.

Tseng, Y.H., Lin, C.J. and Lin, Y.I., 2007. Text mining techniques for patent analysis. Information Processing \& Management, 43(5), pp. 1216-1247.

Wu, J.L., Chang, P.C., Tsao, C.C. and Fan, C.Y., 2016. A patent quality analysis and classification system using self-organizing maps with support vector machine. Applied soft computing, 41, pp. 305-316.

Yoon, B. and Park, Y., 2004. A text-mining-based patent network: Analytical tool for hightechnology trend. The Journal of High Technology Management Research, 15(1), pp.37-50. 